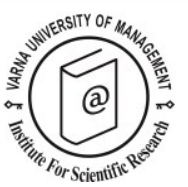

\title{
Examining the role of familiarity, information sources, length of stay and satisfaction to the image perception model
}

\author{
Lluís Prats $^{1}$, Raquel Camprubi ${ }^{2 *}$ and Lluís Coromina ${ }^{3}$
}

Received: 10/06/2015 Accepted: 16/11/2015

\footnotetext{
${ }^{1}$ Associate Professor, Faculty of Tourism, University of Girona, Plaça Ferrater Mora, 1, 17004 Girona, Spain; phone: +34972419720; email: lluis.prats@udg.edu

${ }_{2}^{2}$ Associate Professor, Faculty of Tourism, University of Girona, Plaça Ferrater Mora, 1, 17004 Girona, Spain; phone: +34972419720; email: raquel.camprubi@udg.edu

${ }_{3}^{3}$ Associate Professor, Faculty of Tourism, University of Girona, Plaça Ferrater Mora, 1, 17004 Girona, Spain; Faculty of Economics, University of Girona, Campus Montilivi; phone: 972419720; email: lluis.coromina@udg.edu

* Corresponding author
}

\section{Abstract}

This study examines the effect of familiarity on information sources and the length of stay in a destination, and how these concepts, in turn, affect the image perception model. Data was collected from 603 structured personal interviews carried out in Barcelona (Spain) and structural equation modelling methodology was used to test the hypotheses. Results show that tourists familiar with Barcelona are less likely to consult tourist information. The paper also presents evidence to suggest that the length of stay is the same whether tourists are familiar with the destination or not. Furthermore, we argue that tourist satisfaction is influenced by both cognitive and affective evaluations and that information sources partially influence cognitive evaluations, affective evaluations length of stay and satisfaction. Until now literature has only indicated a tentative relationship between length of stay and destination image, however the outcomes of this study prove that the length of stay in a destination alters its tourism image.

(C) 2016 Varna University of Management. All rights reserved

Keywords: tourist image, familiarity, satisfaction, length of stay, information sources.

Citation: Prats, L., R. Camprubí and L. Coromina (2016) Examining the role of familiarity, information sources, length of stay and satisfaction to the image perception model. European Journal of Tourism Research 13, pp. 5-22

\section{Introduction}

Tourists are becoming increasingly familiar with destinations through repeat visits to the same place. The emergence of low cost connections has also made certain destinations easily accessible. This, in addition to fragmentation of holidays, has made urban destinations, such as Barcelona (Spain), increasingly attractive, and the tourism industry needs to adapt to this new scenario. 
Previous authors who have focused attention on the repetition effect, or familiarity in destinations, were in essence describing and analysing the relationship between this concept and destination image (Baloglu, 2001; Beerli \& Martín, 2004; Chi, 2012; Hernández Maestro, Muñoz Gallego, \& Santos Requejo, 2007; Hong, Lee, Lee, \& Jang, 2009; Ryan \& Pike, 2004). Therefore, their main purpose was to demonstrate that familiarity could modify the image that a tourist has of a destination. In particular, Bruwer \& Lesschaeve (2012), clearly demonstrated that there is a substantial difference between the perceptions of first-time visitors and repeat visitors to wine regions.

Thus, image plays a fundamental role in both the success of tourism destinations and changes in the tourism sector, as well as in tourists' expectations. This means that tourism destinations have to strategically consider the management of their destination image. In this regard, management employs a diversity of distribution channels to encourage people to visit a tourism destination and this implies the need to know how tourists find out about a destination and ascertain what the most costeffective and genuine sources of information for them are (McDowall, 2010). In this sense, target markets needs have to be matched with the most appropriate information sources.

In addition, previous research proved that information sources and length of stay can influence destination image (Baloglu 2000; Gursoy \& McCleary 2004; McDowall 2010). Moreover, the image acquired after visiting the destination also influences tourist satisfaction, and this satisfaction depends on the destination's ability to provide experiences that correspond to tourists' needs and expectations (Bigné, Sánchez, \& Sánchez, 2001).

Considering this background, this paper aims to determine, in a single model, the role of familiarity, information sources, length of stay and satisfaction on the image perception. Therefore, it contributes to academic literature offering a global vision of the role of each construct in a single model. Previous research has evaluated these constructs separately. Thus, this allows having a better knowledge about the tourist behaviour with a holistic point of view of relevant variables that intervene in the process of tourism consumption. This better understanding of the phenomenon has managerial implications as it allows reorienting tourism communication and attributes of the product offered at the destination.

In order to achieve this aim, the existing image perception model was retested and new variables were added in order to check their relevance. The inclusion of familiarity, information sources, length of stay and satisfaction to the standard model will allow better knowledge of the tourist's perception of a destination. Moreover, it will shed light on how DMO's manage their image emission in order to adapt the image message to different subsegments. A final contribution, specifically regarding familiarity, is to bring a deeper understanding of the effects repeat visits have on a tourism destination, especially considering the underdeveloped nature of this issue.

\section{Literature Review}

\section{Destination image conceptualisation}

The relevance of destination image as an influencing factor in consumer behaviour (Bigné, Sánchez, \& Sanz, 2009; Kim \& Richardson, 2003; Ross, 1993; Ryan \& Pike, 2004; Sonmez \& Sirakaya, 2002), and as a conditioning element of destination competitiveness (Hsu, Wolfe, \& Kang, 2004; Ritchie \& Crouch, 2003) have been crucial in the study of destination image.

In addition, the multidisciplinary nature of tourism gives rise to multiple approaches to the study and conceptualisation of tourism destination image. Disciplines such as marketing, anthropology and sociology have contributed to this process of conceptualisation, and as a result it is widely accepted that a tourism image is "the sum of beliefs, ideas, and impressions that a person has of a destination" (Crompton 1979: 18). So, a tourism image is conceived as a mental construction, where the visual component comes in second place, in front of previous knowledge of tourists, their impressions and believes (Echtner \& Ritchie, 1993; Kotler, Haider, \& Rein, 1993; Phelps, 1986), and represents an efficient shortcut for the array of associations that tourists mentally link to the destinaton (Josiassen, Assaf, Woo, \& Kock, 2015). However, there is no consensus 
Prats, L., R. Camprubí and L. Coromina (2016) / European Journal of Tourism Research 13, pp. 5-22

on determining if these impressions are collective or unipersonal (Gallarza, Gil, \& Calderón, 2002).

Consequently, academic literature recognises that tourism image has a complex nature (Gallarza et al., 2002; Tasci \& Gartner, 2007), not only in its conceptualisation but also due to its components, taxonomy and measurement.

\section{Destination image components}

Destination image is considered an attitudinal construct (Baloglu \& McCleary, 1999) and academics agree that tourism image is formed by both cognitive and affective components (Josiassen et al., 2015; Tasci et al., 2007).

Cognition consists of the sum of what is known about a place. Pike and Ryan $(2004,334)$ state "this is awareness, knowledge, or beliefs, which may or may not have been derived from a previous visit". Generally, cognitive evaluations are analysed considering tangible or physical attributes (Baloglu, 2001; Beerli \& Martín, 2004; Bigné et al., 2009) such as infrastructure, places of historical and cultural interest, shopping facilities, nightlife and entertainment, cleanness and weather, among others. Usually, these attributes are measured using 5-7 point Likert scales.

Affective evaluations are related to feelings towards a destination (Baloglu \& McCleary, 1999; Kim \& Richardson, 2003; Ryan \& Pike, 2004) and various authors have attempted to analyse this component (Baloglu, 2001; Beerli \& Martín, 2004; Ryan \& Pike, 2004; Alvarez \& Campo, 2014; Papadimitriou et al., 2015). Russel, Ward and Pratt (1981) managed to develop a measure of affective evaluations in environments, consisting of four semantic difference scales (pleasant/unpleasant, relaxing/stressful arousing/sleepy, and exciting/gloomy). After Baloglu and Brinberg (1997) assessed its usefulness in tourism destinations, numerous tourism image studies have used these measures (Baloglu \& Mangaloglu, 2001; del Bosque \& San Martín, 2008; Lin, Morais, Kerstetter, \& Hou, 2007; Ryan \& Pike, 2004). However, considering that the affective component includes subjective attitudes to the destination's properties, some researchers have used free descriptions from the respondents to better understand this image dimension (Tasci et al., 2007).

In general, tourism image studies have focused on cognitive perceptions, whereas only a small part centres its attention on affective evaluations (Tasci et al., 2007). However, in the late 1990s and during the 2000s there has been a tendency to analyse these two components jointly; particularly after Baloglu and McCleary (1999) demonstrated that cognitive and affective components contribute to overall image formation, although affective evaluations have more influence (Alvarez \& Campo, 2014). In this sense, destination image should be considered as a multi-dimensional phenomenon that includes not only beliefs or knowledge about the place's attributes, but also the individuals' feelings towards the tourist destination" (del Bosque \& San Martín, 2008). For this reason, it is considered that both components are needed to evaluate the perceived image of a place correctly, thus the following hypothesis is proposed:

H1: Positive cognitive evaluations of destination image are correlated with positive affective evaluations of destination image.

\section{Satisfaction}

Satisfaction is a relevant concept in tourism and marketing research. However, the literature on its conceptualisation continues to be vague (Baker \& Crompton, 2000; del Bosque \& San Martín, 2008; Millán \& Esteban, 2004). Churchill and Surprenant (1982, p. 493) defined the concept of satisfaction as an "outcome of purchase and use resulting from the consumer's comparison of the rewards and cost of purchase in relation to expectations and, as an attitude because it can be measured as the total satisfaction from various attributes of the product or service". Tse and Wilton (1988, p. 204) defined satisfaction as a "consumer response to the evaluation of the perceived difference between expectations and final result after consumption", and Fornell (1992, p. 11) defined this concept as the "overall evaluation after purchase". Millán and Esteban (2004) reported that customer satisfaction is recognised as the final step of a psychological process because it is perceived as the final result of all activities carried out 
Examining the role of familiarity, information sources, length of stay and satisfaction to the image perception model.

during the process of purchase and consumption. Furthermore, del Bosque and San Martín (2008) stated that studies which have used a cognitive approach consider consumer satisfaction as a post consumption evaluation that meets or exceeds expectations, that an affective approach considers consumer satisfaction as an emotional response derived from a consumption experience and that cognitive-affective studies consider satisfaction as an individual's cognitive-affective state, derived from a tourist experience.

A number of studies have been conducted in order to measure satisfaction in different tourism sectors. For example, there have been studies of customer satisfaction in travel agencies (Millán \& Esteban, 2004), restaurants (Nam \& Lee, 2011; Ryu, Han, \& Jang, 2010; Wu \& Liang, 2009), heritage sites (PalauSaumell, Forgas-Coll, Sánchez-García, \& Prats-Planagumà, 2013), hotels (Berezan, Raab, Yoo, \& Love, 2013; Kim, Ma, \& Kim, 2006; Kralj \& Solnet, 2010; Li, Ye, \& Law, 2013) and even active tourism (Palau-Saumell, Forgas-Coll, Sánchez-García, \& PratsPlanagumà, 2014). In particular, the relationship between destination image and satisfaction gathered some momentum in tourism literature, with most studies focusing on cognition (Bigné et al., 2001; C. F. Chen \& Tsai, 2007; Chi \& Qu, 2008; Lee, 2009). Bigné, et al. (2001) and Chi and Qu (2008) assessed the relationship between the components of destination image and satisfaction. The results supported the theory that destination image directly influences satisfaction, reporting that positive cognitive and affective images lead to greater satisfaction. This relationship was also tested and supported by Lee (2009). Hence, destination image is critical in directly determining satisfaction and it can be regarded as its antecedent. Therefore:

H2a: Cognitive evaluations of destination image have a significant and direct impact on tourist satisfaction.

$H 2 b$ : Affective evaluations of destination image have a significant and direct impact on tourist satisfaction.

\section{Information sources}

Several studies have considered the relevance of information sources as a conditioning factor in the image formation process (Baloglu \& McCleary, 1999; Baloglu, 2000; Chen, 2000; Gursoy \& Chen, 2000; Gursoy \& McCleary, 2004). Individuals perceive an image of a place via a process of internalisation of knowledge gained over time though various information sources such as books, documentaries, advertising, recommendations, etc. Earlier, Gunn (1972) in her pioneering work outlining the 7-stage tourist experience, revealed the stages that change the perceived image of individuals, from an organic image produced by general and diverse non-tourist information, to an induced image resulting from an interest in being informed about the destination and its attractions; and finally, a modified tourist image produced by the re-evaluation of the experience at the destination once back home. Thus, "image formation is a dynamic process affected by the information gained by the consumer" (Alvarez \& Campo, 2011, p. 320).

Gartner (1994) gave insight into the various types of information sources and identified a continuum of eight different agents that act independently, or in some combination, to form a destination image unique to the individual. Each one of these agents represents a type of information source for tourists, which contributes to image perception and influences their destination selection process. In addition, Tasci and Gartner (2007) suggest the controllable and uncontrollable character of these image formation agents, determining supply-side agents as controllable, independent agents (educational materials, news, movies, etc.) as semi-controllable, and demand-side agents (tourists) as uncontrollable.

Some authors have tried to determine the influence of information sources in tourism image components (Alvarez \& Campo, 2011; Baloglu \& McCleary, 1999; McDowall, 2010). Specifically, Alvarez and Campo (2011) determine that uncontrollable sources of information have a lower impact, being positive for destinations that are often negatively reflected in international news. In their influential contribution, Baloglu and McCleary 
(1999) found that information sources influence both cognitive and affective evaluations. In particular, this study evidenced the power of word-of-mouth as having an influence on the three cognitive variables analysed (quality of experience, attractions and value/environment). In the same way, McDowall (2010) demonstrated that recommendations from friends and relatives were the most common source of information for both first-timers and repeaters. Hanlan and Kelly (2005) found that the destination brand image of Byron Bay (Australia) has been formed predominately through word-of-mouth and autonomous agents, particularly tourist guides. Bruwer and Thach (2013), similarly, confirmed that word-ofmouth is the primary source of information for both first-time and repeat visitors to a wine tourism destination. They also found that firsttime visitors use more brochures and tourist office information than repeat visitors. In the same way, other studies highlight the relevance of guidebooks, brochures (McDowall, 2010) and Internet as relevant information sources (Frías, Rodríguez, Alberto Castañeda, Sabiote, \& Buhalis, 2012; McCartney, Butler, \& Bennett, 2008; McDowall, 2010).

In summary, it can be stated that the final image perceived is affected by the information sources used, and Alvarez and Campo (2011) reinforce this idea, thus the following hypothesis is proposed:

H3a: Types of information sources significantly influence cognitive evaluations.

H3b: Types of information sources significantly influence affective evaluations.

\section{Length of stay}

Length of stay at tourism destinations is a topic that has recently received attention from tourism academics, and a number of studies have been conducted in this area. Length of stay has been studied as a driving factor of tourist expenditure by some authors (García-Sánchez, Fernández-Rubio, \& Collado, 2013; Salmasi, Celidoni, \& Procidano, 2012; Thrane \& Farstad, 2012) and sociodemographic and travel characteristics have been detected as determinant factors of length of stay (Alegre \& Pou, 2006; Barros \& Machado, 2010; Gokovali, Bahar, \& Kozak,
2007; Gomes de Menezes, Moniz, \& Cabral, 2008). However, academic literature has paid little attention to the relationship between destination image and length of stay. In particular, Machado (2010: 446) observed that although "destination image and length of stay have been analysed independently from each other, it is also possible to define them simultaneously"; thus this author in his study determined that positive evaluations of destination attributes increase the length of stay.

The process of forming an image of a specific tourism destination starts when the individual is planning the holiday and ends when the tourist returns home (Baloglu \& McCleary, 1999). Consequently, it can be interpreted that the time spent in a destination influences the tourism image of that destination. In other words, the length of stay might alter or modify the tourism image of the destination after the visitor leaves the destination. Therefore, length of stay can be understood as an antecedent of two destination image components: cognitive and affective (Fakeye \& Crompton, 1991; Vogt \& Stewart, 1998), resulting in the following hypotheses:

H4a: Length of stay in a destination significantly influences cognitive evaluations.

H4b: Length of stay in a destination significantly influences affective evaluations.

Moreover, length of stay can be influenced by information sources used by tourists to plan the visit, although very little literature has focused on the relationship between these two issues. Particularly, Fodness and Murray (1997) in their study of Florida travellers concluded that increases in length of stay were positively associated with the number of sources used; later, along the same lines, these authors observed that higher levels of information search are positively associated with longer stays (Fodness \& Murray, 1999).

In addition, Richards (2002) also found that the type of information sources used can vary according to length of stay. At the same time he determined that the use of guidebooks and Internet increased substantially for those staying two weeks or more, while mass media 
varied little with length of stay. However, not all the studies demonstrated that a relationship existed between these two issues, for example Luo, Feng, and Cai (2004) concluded that there are no significant differences in length of stay among tourists who use Internet and those who use other information sources. So, further research is needed to determine if there really is evidence that information sources can influence decisions regarding length of stay. Therefore, the following hypothesis is proposed:

H4c: The length of stay is significantly influenced by types of information sources used.

\section{Familiarity}

Several authors have explored the relevance of travel experience and previous visits in conditioning tourist image perception (Baloglu \& McCleary, 1999; Beerli \& Martín, 2004; Gunn, 1972; Ryan \& Pike, 2004). Previous visits to or direct experience of a destination is likely to alter and modify the image of tourism destinations. In 2004, Pike and Ryan analysed the market positions of a competitive set of destinations in New Zealand though a comparison of cognitive, affective and conative perceptions. As suggested by researchers, the actual cause of image variations perceived by visitors either came from perceptions gained on previous visits. This means that previous visits or direct experience with a destination is likely to alter and modify the image they have of the destination. Gursoy and Chen (2000) reported differences between first-time and repeat German, French and British travellers in using information sources. This study highlights that past trip experience significantly influenced travellers' use of information sources. Gursoy and McCleary (2004) found that the way people searched for information varied according to the dimensions of familiarity and the expertise travellers had regarding a destination. The authors reported that previous knowledge of a destination influenced external information searches and decision-making, and that the provision of better quality and tailored information increased the likelihood of a visit to the destination. In particular, Woodside and King (2001) and Woodside and Dubelaar (2002) reported that tourists who had never visited a destination were more likely to consult guidebooks before the trip and use them more often than those who had previously visited the destination. Likewise, Carneiro and Crompton (2010) concluded that the less familiar people were with a destination, the more likely they were to search for information about it. Differently to all these studies, Baloglu (2001) discusses that the amount of information sources used should be considered jointly to previous experience to measure familiarity, considering that previous experience is one of the main determinants but not the only one. However, considering the relevance of both issues separately in previous research, in this study familiarity is considered unidimensional and based only on previous experience; and causality between familiarity and information sources is explored. Therefore:

H5a: Familiarity with a destination is likely to be negatively related to the search for information for that destination.

The relationship between familiarity and length of stay has also been addressed in academic literature. In general, studies demonstrate that a higher familiarity with the destination, contributes to longer stays (Alegre \& Pou, 2006; Gokovali et al., 2007; Gomes de Menezes et al., 2008), so, repeat visitors tend to spend more time in the destination. However, Machado's (2010) findings are not consistent with this generalisation. $\mathrm{He}$ concluded that repeat visits negatively affect the length of stay in the case of Madeira.

Considering that previous research confirms interdependence of these two variables, although different effects are found, the following hypothesis is proposed:

H5b: Familiarity with a destination has a significant impact on the length of stay in that destination.

After carefully revising the literature, we propose the following structural model of destination image with the inclusion of the expected hypotheses, as shown in Figure 1. The model proposes that, on one hand, familiarity has a significant impact on information sources and length of stay; and, on 


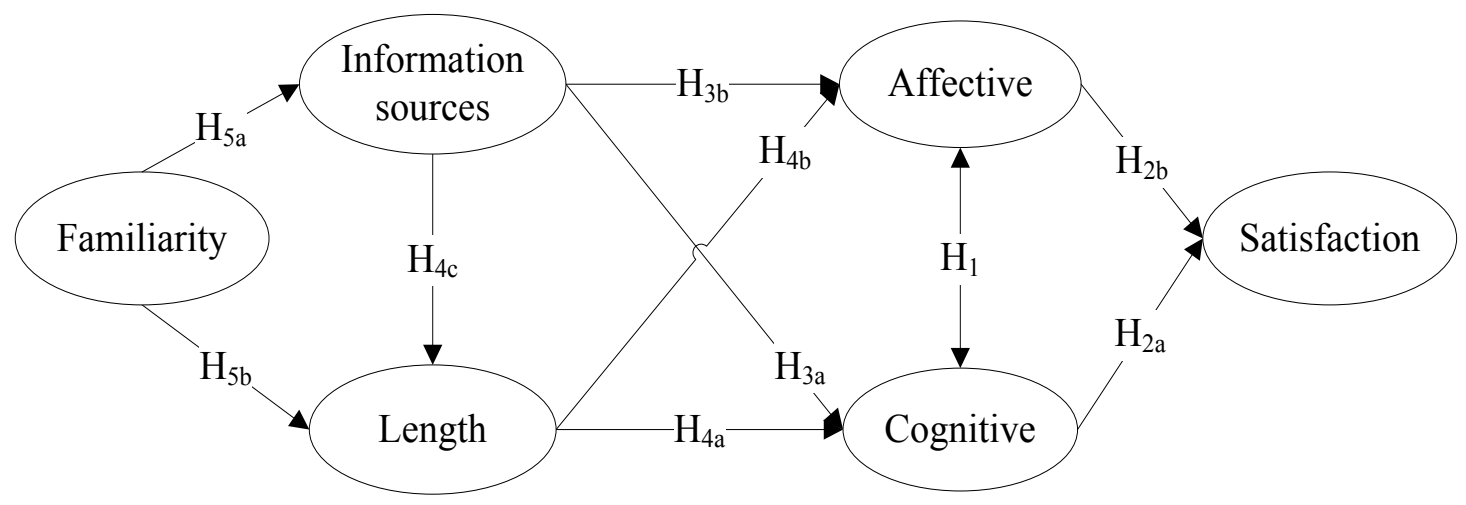

Figure 1. Hypotheses model of destination image

the other hand, length of stay has a significant impact on destination image perceptions. This is a new approach, considering that previous research has not evaluated all the constructs together in the same structural model, even though several of these constructs have been evaluated separately. The model suggests that level of familiarity influences information sources used before travelling and decisions related to length of stay. At the same time, information sources and length of stay are likely to play significant roles in cognitive and affective evaluations of destination image. This model also reaffirms the significant and direct relationship between image perception constructs and satisfaction.

\section{Methodology}

\section{Survey instrument and measurement}

The survey was developed on the basis of the literature review in order to capture the key determinants of destination image. The questionnaire is made up of 29 questions with seven sections and considers sample profile items and the theoretical constructs developed in the conceptual model, the measurement of the constructs is shown in Table 1. The survey measured the following constructs: Cognitive evaluation, affective evaluations, tourists' satisfaction, information sources, length of stay and familiarity with the destination (measures in Table 1). The seventh section was the sociodemographic data, which referred to gender, age, level of education, and place of residence.

\section{Study site}

Barcelona was chosen as a case study, considering that it is one of the main city tourism destinations in Europe for both its cultural and architectural attractiveness. In 2012 it received around 7.4 million tourists. Barcelona has been postulated as a major tourism destination, especially after hosting the 1992 Olympic Games, which contributed positively to its urban regeneration, with new infrastructures and a new waterfront. This positioned Barcelona in the collective imagery around the world, making it the third European city, after Paris and London, according to The City Brand Barometer (Hildreth, 2007). In 2009 a new strategic plan was drafted to improve tourism planning and management in the city. During the analysis process a number of studies were done. The results of one study estimated the economic impact of tourism in Barcelona at 20 million Euros a day in 2007 (Suriñach, 2010), and this number has probably increased, considering the growth of tourism in recent years, despite the economic crisis. From the 1990s to the present, Barcelona has experienced a high diversification of its supply and demand, becoming not only a relevant cultural destination, but also an important shopping and business centre. It is ranked the third city in the world in the International Congress and Convention Association Ranking (ICCA, 2011) in terms of number of meetings, and the fourth European city in terms of number of visitors, after London, Paris and Rome, according the 
Examining the role of familiarity, information sources, length of stay and satisfaction to the image perception model.

Table 1. Conceptual constructs and their measurement

\begin{tabular}{|c|c|c|c|}
\hline Constructs & Authors & Variables & Measurement \\
\hline Cognitive evaluations & $\begin{array}{l}\text { Baloglu (2000) } \\
\text { Beerli and Martin (2004) } \\
\text { Pike and Ryan (2004) } \\
\text { Prayag (2012) } \\
\text { Wang and Davidson (2010) }\end{array}$ & $\begin{array}{l}\text { Well-developed transport } \\
\text { infrastructure } \\
\text { Good quality tourist } \\
\text { infrastructure } \\
\text { Good variety of leisure and } \\
\text { recreation possibilities }\end{array}$ & $\begin{array}{l}\text { A 5-point Likert-type scale } \\
\text { (“ } 1 \text { = strongly disagree" and } \\
\text { " } 5 \text { = strongly agree). }\end{array}$ \\
\hline Affective evaluations & Russel et al. (1981) & $\begin{array}{l}\text { Arousing place } \\
\text { Exciting place } \\
\text { Pleasant place }\end{array}$ & $\begin{array}{l}\text { A } 5 \text {-point Likert-type scale } \\
\text { (" } 1 \text { = strongly disagree" and } \\
\text { " } 5 \text { = strongly agree). }\end{array}$ \\
\hline Satisfaction & $\begin{array}{l}\text { Bigné et al. (2001) } \\
\text { Chi and Qu (2008) } \\
\text { Lee (2009) }\end{array}$ & $\begin{array}{l}\text { Pleased with my decision } \\
\text { Satisfied expectations } \\
\text { It was what I needed }\end{array}$ & $\begin{array}{l}\text { A } 5 \text {-point Likert-type scale } \\
\text { (" } 1 \text { = strongly disagree" and } \\
\text { " } 5 \text { = strongly agree). }\end{array}$ \\
\hline Information sources & $\begin{array}{l}\text { Baloglu (2001) } \\
\text { McDowall (2010) }\end{array}$ & $\begin{array}{l}\text { Official website } \\
\text { Other online sources } \\
\text { Newspapers } \\
\text { Travel magazines } \\
\text { Traditional travel agency } \\
\text { Guidebooks } \\
\text { Previous experience } \\
\text { Recommendation of } \\
\text { friends/relatives }\end{array}$ & $\begin{array}{l}\text { What sources have you } \\
\text { used from the list? Multiple } \\
\text { categories; converted to } \\
\text { dichotomous for each item. }\end{array}$ \\
\hline Length of stay & $\begin{array}{l}\text { Gomes de Menezes et al. } \\
\text { (2008) } \\
\text { Gokovali et al. (2007) }\end{array}$ & Duration of the stay & $\begin{array}{l}\text { Length of stay in Barcelona? } \\
\text { Numerical response. }\end{array}$ \\
\hline Familiarity & $\begin{array}{l}\text { Carneiro and Crompton } \\
\text { (2010) }\end{array}$ & Previous visit & $\begin{array}{l}\text { Is it your first time in } \\
\text { Barcelona? Dichotomous } \\
\text { response (Yes/No) }\end{array}$ \\
\hline
\end{tabular}

\section{Euromonitor International's Top City Destinations Ranking (2011).}

\section{Data collection and sample profile}

The sample used was visitors who stopped at the Sagrada Familia, which was chosen for its relevance as an attracting node, with over 3.2 million visitors in 2011. Interviewers carried out the survey over a three-month period, from February to April 2012 using questionnaires. Systematic random sampling was used to select the survey participant, which involved choosing every $x^{\text {th }}$ element after a random start. In this case, $x^{\text {th }}$ was determined as 16.

Before collecting data for the final questionnaire, a pilot study was undertaken in December 2011 to examine the internal consistency of the questionnaire. The pilot study was conducted on 100 randomly selected visitors at Sagrada Familia and a total of 40 were considered valid.

Data was collected using a tablet and the software Iformbuilder to fill out questionnaires. The main advantage of this data collection method is that the database is generated automatically, reducing possible typing mistakes. After a validation process of the data collected, 5 cases were eliminated due to some inconsistency in the answers, thus the final sample was made up of 603 respondents, representing a maximum margin of error of $4 \%$, at a $95 \%$ level of confidence.

Table 2 shows the frequency and the percentage the variables used in the sample respondents' profile such as gender, age, education and place of residence. The profile of sample respondents was mostly made up of young adults (22 to 45 years old), followed by the 46-65 age range. The majority were well educated with degree level qualifications. The largest number of tourists held a university degree; this was followed by high school and to a much lesser extent, primary school qualifications. The percentage of respondents according to gender is not significantly different for males and females.

A total of fifty-two countries of residence were identified, these were then classified into four European regions and four continents (America was divided into North and South). United 
Kingdom (UK) constituted almost $14 \%$ of the total respondents and Spain, with $11 \%$, was in second position, followed by France (10\%). After this came United States of America, Germany, Italy and Brazil with more than $9 \%$, almost $6 \%, 5.6 \%$ and $5 \%$ of the total number of respondents correspondingly.

Geographic concentration in terms of travellers' place of residence was evident as central Europe (France, UK, Germany, Italy, Spain, The Netherlands, etc.) contributed with more than half of the holidaymakers, followed by South America (Brazil, Argentina, Mexico, etc.) and North America (USA and Canada). Approximately $5 \%$ of the holidaymakers resided in Eastern Europe (Russia, Poland, etc.), Northern Europe (Sweden, Finland, Denmark and Norway), S.E. Europe (Romania, Ukraine, etc.) and Asia respectively. Finally, other continents were identified with 5 respondents from Australia and 1 from Africa.

Table 2. Socio-demographic profile of respondents $(n=603)$

\begin{tabular}{lcc}
\cline { 2 - 2 } & Frequency & $\%$ \\
\hline Gender & & \\
Male & 280 & 46.4 \\
Female & 323 & 53.6 \\
\hline Age & 38 & \\
Under 22 & 391 & 6.3 \\
From 22 to 45 & 159 & 64.8 \\
From 46 to 65 & 15 & 26.4 \\
Over 65 & & 2.5 \\
\hline Education & 470 & 78.0 \\
University degree & 110 & 18.2 \\
High School & 23 & 3.8 \\
Primary School & & \\
\hline Place of residence & 365 & 60.5 \\
Central Europe & 70 & 11.6 \\
South America & 67 & 11.1 \\
North America & 29 & 4.8 \\
Eastern Europe & 22 & 3.7 \\
Northern Europe & 22 & 3.7 \\
South-eastern Europe & 22 & 3.7 \\
Asia & 6 & 1.0 \\
Others & & \\
\hline
\end{tabular}

\section{Data analysis}

The causal model from Figure 1 is analysed using Structural Equation Modelling -SEM(Bollen, 1989; Kline, 2011). The theoretical model contains cognitive evaluations, affective evaluations and tourists' satisfaction concepts, each of which are expected factors composed of three items. In order to estimate the model, in terms of adequacy - that is to say reliability, validity and convergent validity- these constructs must be studied. This procedure will be carried out using Confirmatory Factor Analysis -CFA- (Brown, 2006) considering three indicators for each latent factor (cognitive evaluations, affective evaluations and tourists' satisfaction).

Once the adequacy of the constructs is assessed, factor scores for each of these constructs will be created for posterior causal model estimation. Causal relationships will be estimated with SEM using Robust Maximum Likelihood (MLR) estimator for parameter estimation. Missing values are dealt with using the maximum-likelihood estimation procedure, which uses all available information from the variables. Mplus 7 is used for the analyses.

\section{Results}

\section{Confirmatory factor analysis}

Firstly, adequacy of the items for different theoretical constructs will be studied. CFA is used to evaluate whether the items belong to a specific latent construct. Table 3 shows the CFA estimates for nine items that are related to tourists' satisfaction, affective and cognitive evaluations factors.

Results in Table 3 show that factor loadings of the items are related to their theoretical latent factor. For instance, the items arousing, exciting and pleasant place belong to the factor named affective evaluations. Factor loadings are high and statistically significant, showing convergent validity of the data.

Acceptable fit measures for SEM models are Root Mean Square Error of Approximation (RMSEA) values of 0.05 or lower are an indication of acceptable fit (Hu \& Bentler, 1999; MacCallum, Browne, \& Sugawara, 1996). For incremental fit indices, Comparative Fit Index $(\mathrm{CFI})$ and Tucker-Lewis index (TLI), which are used to calculate improvements over competing models, values higher than 0.90 for these two indices indicates an acceptable model fit (Hu \& Bentler, 1999). In the paper, evaluation of these fit measures are combined with the examination of Modification Indices (MI), Expected Parameter Change (EPC) and the power of the test in order to inspect for 
Examining the role of familiarity, information sources, length of stay and satisfaction to the image perception model.

Table 3. Confirmatory Factor Analysis

\begin{tabular}{|c|c|}
\hline & Factor Loading \\
\hline \multicolumn{2}{|l|}{ Affective evaluations (CR=0.80; $A V E=0.57)$} \\
\hline Arousing place & $0.64^{\star \star \star}$ \\
\hline Exciting place & $0.81^{* * *}$ \\
\hline Pleasant place & $0.80^{\star * *}$ \\
\hline \multicolumn{2}{|l|}{ Cognitive evaluations (CR=0.83; $A V E=0.56)$} \\
\hline Well-developed transport infrastructure & $0.68^{* * *}$ \\
\hline Good quality tourist infrastructure & $0.83^{* * *}$ \\
\hline Good variety of leisure and recreation possibilities & $0.72^{\star * *}$ \\
\hline \multicolumn{2}{|l|}{ Satisfaction $(C R=0.78 ; A V E=0.65)$} \\
\hline I'm pleased with my decision to visit Barcelona & $0.76^{* * *}$ \\
\hline Barcelona has satisfied my expectations & $0.92^{* * *}$ \\
\hline Barcelona is what I needed & $0.72^{\star \star *}$ \\
\hline
\end{tabular}

CR = Composite Reliability; AVE = Average Variance Extracted.

*** p. value $<.001$

Table 4. Discriminant validity

\begin{tabular}{llll} 
& Satisfaction & Affective & Cognitive \\
\hline Satisfaction & 0.806 & & \\
Affective & 0.554 & 0.755 & \\
Cognitive & 0.414 & 0.432 & 0.748 \\
\hline
\end{tabular}

possible model misspecification (Saris, Satorra, \& van der Veld, 2009).

The estimated CFA model with three latent factors (affective, cognitive evaluations and tourists' information) has acceptable fit according the most used fit measures for SEM models. The obtained fit measures are $x^{2}=$ 44.553, degrees of freedom $(d f)=24, p=0.007$; RMSEA $=0.038$. In addition, incremental fit indices as the $\mathrm{CFI}=0.984$ and $\mathrm{TLI}=0.977$ have been used. No misspecifications are found according MI, EPC and power of the test.

Validity and reliability are proved for these latent constructs. Reliability is confirmed because the Composite Reliability (CR) indices of each of the dimensions obtained are higher than 0.60 (Bagozzi \& Yi, 1988); in this case it is 0.80 for affective evaluations, 0.83 for cognitive evaluations and 0.78 for tourists' satisfaction. Convergent validity is demonstrated because factor loadings, see Table 3 , are statistically significant and greater than 0.50 (Bagozzi \& Yi, 1988) and the Average Variance Extracted (AVE) for each of the factors is higher than 0.50 (Fornell \& Larcker, 1981); in this case it is 0.57 for affective evaluations, 0.56 for cognitive evaluations and 0.65 for tourists' satisfaction. The third aspect, discriminant validity of the latent constructs is assessed by means of the average variance extracted (Fornell \& Larcker, $1981)$, this requires that a latent construct has more variance with its indicators than with other latent constructs of the model, which means that the square root of the AVE for each construct is higher than the estimated correlation between those constructs. Results of discriminate validity are shown in Table 4.

Table 4 shows how discriminant validity holds; values in the diagonal (square root of the AVE) are higher than values in the off-diagonal. Results from reliability and validity show the adequacy of creating a factor score for those three latent constructs, which will be used for estimating the causal model in the next step.

\section{Causal relationships}

Estimation of the causal model is carried out using Structural Equation Modelling with a robust maximum Likelihood (MLR) estimator. The model of destination image estimated in Figure 1 did not fit the data according to the traditional fit measures (model I in Table 5) and the model was misspecified (Saris et al., 2009). Inspection of Modification Indices (MI), Expected Parameter Change (EPC) and power of the test suggested the inclusion of two additional plausible causal paths. Figure 5 shows the fit indices for the initial model in Figure 1 (Model I) and the model with the two additional causal paths (Model II) - effect of 'recommendation' on 'official internet websites' and the effect of 'previous experience' on 'recommendation'. 
Table 5. Fit indices for estimated models

\begin{tabular}{llll}
\hline Fit index & $\begin{array}{l}\text { Recommended } \\
\text { value }\end{array}$ & Model I & Model II \\
\hline $\mathrm{X}^{2} /$ d.f.; & $<3.00$ & $36.693 / 14=2.62 ;$ & $15.412 / 12=1.284 ;$ \\
p.value & & 0.0008 & 0.220 \\
CFI & $>0.90$ & 0.947 & 0.992 \\
TLI & $>0.90$ & 0.863 & 0.976 \\
RMSEA & $<0.05$ & $0.052 ; 90 \% \mathrm{Cl}(0.032 ; 0.073)$ & $0.022 ; 90 \% \mathrm{Cl}(0.000,0.050)$ \\
\hline
\end{tabular}

CFI = Comparative Fit Index; RMSEA = Root Mean Square Error of Approximation;

$\mathrm{TLI}=$ Tucker-Lewis Index.

Table 6. Causal relationships in the structural Model II

\begin{tabular}{|c|c|c|}
\hline & Causal Relationships & $\begin{array}{l}\text { Parameter } \\
\text { Estimation }\end{array}$ \\
\hline $\mathrm{H}_{1}$ & Cognitive $\leftrightarrow$ Affective & $0.138^{* * *}$ \\
\hline $\mathrm{H}_{2 \mathrm{a}}$ & Cognitive $\rightarrow$ Satisfaction & $0.141^{* * *}$ \\
\hline $\mathrm{H}_{2 \mathrm{~b}}$ & Affective $\rightarrow$ Satisfaction & $0.314^{* * *}$ \\
\hline \multirow[t]{4}{*}{$\mathrm{H}_{3 a}$} & Internet Official Web $\rightarrow$ Cognitive & $0.113^{*}$ \\
\hline & Guidebooks $\rightarrow$ Cognitive & -0.010 \\
\hline & Previous experience $\rightarrow$ Cognitive & -0.029 \\
\hline & Recommendation $\rightarrow$ Cognitive & 0.055 \\
\hline \multirow{4}{*}{$\mathrm{H}_{3 b}$} & Internet Official Web $\rightarrow$ Affective & 0.040 \\
\hline & Guidebooks $\rightarrow$ Affective & $0.096^{*}$ \\
\hline & Previous experience $\rightarrow$ Affective & -0.028 \\
\hline & Recommendation $\rightarrow$ Affective & $0.085^{+}$ \\
\hline $\mathrm{H}_{4 a}$ & Length $\rightarrow$ Cognitive & $0.033^{* *}$ \\
\hline $\mathrm{H}_{4 b}$ & Length $\rightarrow$ Affective & $0.035^{\star \star}$ \\
\hline \multirow[t]{4}{*}{$\mathrm{H}_{4 \mathrm{c}}$} & Internet Official Web $\rightarrow$ Length & -0.204 \\
\hline & Guidebooks $\rightarrow$ Length & 0.160 \\
\hline & Previous experience $\rightarrow$ Length & $-0.631^{* *}$ \\
\hline & Recommendation $\rightarrow$ Length & $0.389^{* *}$ \\
\hline \multirow[t]{4}{*}{$\mathrm{H}_{5 \mathrm{a}}$} & Familiarity $\rightarrow$ Internet Official Web & $-0.597^{* *}$ \\
\hline & Familiarity $\rightarrow$ Guidebooks & $-0.545^{\star \star *}$ \\
\hline & Familiarity $\rightarrow$ Previous experience & $5.185^{\star \star *}$ \\
\hline & Familiarity $\rightarrow$ Recommendation & $-0.612^{* *}$ \\
\hline $\mathrm{H}_{5 b}$ & Familiarity $\rightarrow$ Length & 0.310 \\
\hline \multicolumn{3}{|c|}{ Additional causal effects: } \\
\hline & Recommendation $\rightarrow$ Internet official web & $-0.598^{\star *}$ \\
\hline & Previous experience $\rightarrow$ Recommendation & $0.653^{*}$ \\
\hline
\end{tabular}

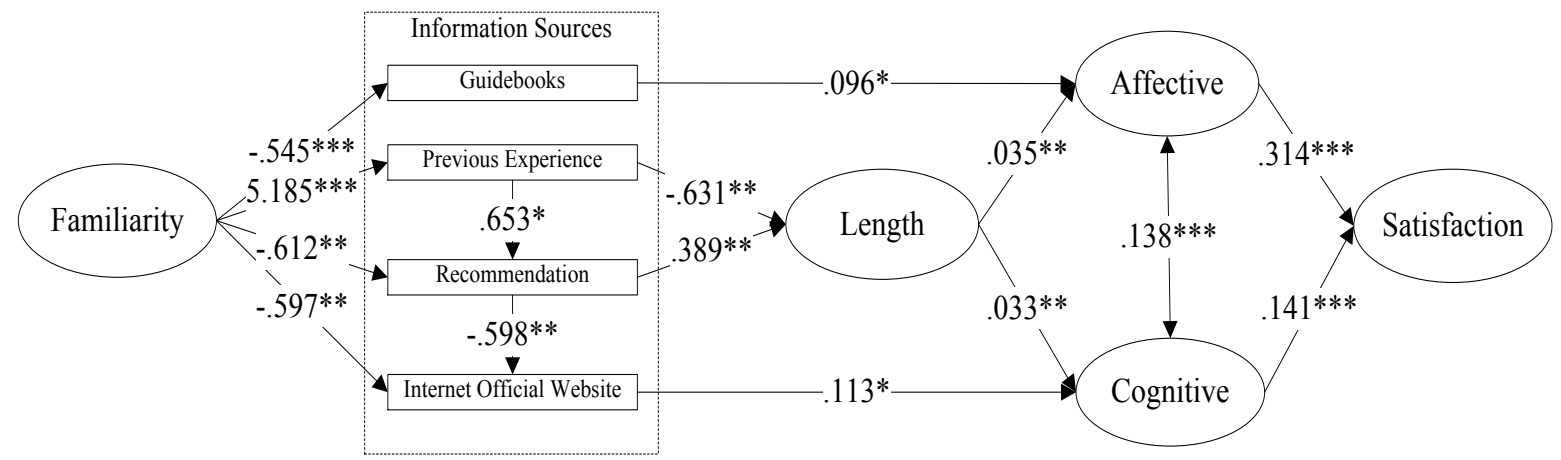

Note: ${ }^{* *} \mathrm{p}$-value $<0.001 ;{ }^{* *} \mathrm{p}$-value $<0.01$; ${ }^{*} \mathrm{p}$-value $<0.05$

Figure 2. Significant estimates for Model II 
After the inclusion of these causal effects, Model II has good fit measures (Chi-squared= 15.412, $d f=12, p=0.220$; RMSEA $=0.022,90 \%$ confidence interval $(0.000 ; 0.050) ; \mathrm{CFI}=0.992$; $\mathrm{TLI}=0.976$ ), and no additional misspecifications were found.

Table 6 shows the estimates for the causal relationships in the structural model and Figure 2 shows the significant paths with the estimates in Model II.

The two additional paths are shown at the bottom of Table 6 (Additional causal effects). The first additional significant path in Model II is the effect of 'recommendation' on 'official internet websites', which is negative, meaning that the higher the recommendation, the less searches there are on official Internet websites for a destination. The second is the effect of 'previous experience' on 'recommendation', which is positive. This means that tourists not only use the information from their own previous experience at the destination, they also use recommendations from friends and relatives. They are probably searching for elements or attractions they missed on their previous occasions, or simply better places to stay or eat.

Results in Table 6 show the confirmation of some of the hypotheses. The first and second hypotheses, which are broadly studied in the literature, show concordance with previous studies. Cognitive and affective evaluations are positively correlated $\left(\mathrm{H}_{1}\right)$ and both of them $\left(\mathrm{H}_{2 a}\right.$ and $\mathrm{H}_{2 \mathrm{~b}}$ ) are predictors that directly and positively affect the tourist satisfaction in the destination. In more detail, we found that affective assessments have a higher influence than cognitive assessments. Hence, destination image is critical in directly determining satisfaction levels as most studies reported (Bigné et al., 2001; C. F. Chen \& Tsai, 2007; Chi \& Qu, 2008; Lee, 2009). Thus, Hypothesis 1 and 2 are held.

The third hypothesis is related to the sources of information as a predictor for cognitive and affective evaluations. Hypothesis $3 a$ and $3 b$ are accepted, however results show that four information sources (newspapers, travel magazines, traditional travel agency and other online sources) are non-significant in the model, not shown in Figure 2 and Table 6 . Results show that official websites positively influence the cognitive evaluation, which means that the information obtained from official websites of the destination affects the cognitive evaluations of tourists visiting that destination. The remaining sources of information (guidebooks, previous experience and recommendation) do not affect the cognitive evaluation of tourists. Guidebooks (and to a lesser degree, recommendation) positively influence the affective evaluation of the tourists at a destination, while the remaining sources are not significant. Therefore, the results partially agree with the findings of Baloglu and McCleary (1999) and McDowall (2010). In summary, the third hypothesis shows that official websites positively influence cognitive evaluations and guidebooks positively influence affective evaluations.

The fourth hypothesis, which involves length, is accepted. The length of stay positively influences the cognitive $\left(\mathrm{H}_{4 \mathrm{a}}\right)$ and affective $\left(\mathrm{H}_{4 b}\right)$ evaluations to almost the same degree. Thus, the more time tourists stay in the destination, the higher their cognitive and affective evaluations are of the destination. This result emphasised Machado's (2010) study, which determined that a positive relationship existed between length of stay and destination image. Finally, $\mathrm{H}_{4 \mathrm{c}}$ relates used information sources on the length of the stay. In this case, guidebooks and internet official website searches are not significant, thus they do not influence the length of stay. Results show that previous experience has a significant and negative influence, which means that tourists that have used previous experience at the destination as a relevant information source spend less time on subsequent visits to the destination. On the other hand, recommendation positively influences the length of stay, meaning that recommended tourists will stay at the destination longer. In fact, this study is partially in line with previous research conducted by Luo et al. (2004) who concluded that there is no difference in length of stay among tourists that have used Internet or alternative information sources. 
Results of hypothesis $5 \mathrm{a}$ show that tourists, familiar with the destination, use fewer information sources (such as the destination' official websites, guidebooks and the recommendations) than non-familiar tourists. This makes sense because these tourists have already visited the destination, this explains that first-time visitors are more likely to look for information about the destination than repeaters, and that tourists already familiar with the destination use their previous experience more. Hence, hypothesis $5 a$ is accepted and the results are in line with other studies (Baloglu, 2001; Carneiro \& Crompton, 2010; Woodside \& Dubelaar, 2002; Woodside \& King, 2001), whose findings reported that the more familiar tourists were with a destination, the less likely they were to consult information sources.

Since information sources are dichotomous variables, a logistic regression was carried out where familiarity with the destination is the predictive variable. Results of logistic regression are expressed in odd-ratios, which are 0.550 for familiarity on official websites, 0.580 for familiarity on guidebooks, 0.542 for familiarity on recommendation. The interpretation is the following: the odds of success are defined as the ratio of the probability of success over the probability of failure. Thus, the probability that a tourist 'familiar' with Barcelona uses official websites of the destination is 0.55 times the probability of a tourist who is not 'familiar' with Barcelona. This means that the probability that a tourist not familiar with Barcelona will use official websites, guidebooks of the destination and recommendations is approximately twice that of someone familiar with the destination.

Effect of familiarity on length of stay is not statistically significant, thus hypothesis $5 \mathrm{~b}$ is not supported. Results show that length of stay is not directly influenced by the fact tourists are familiar (or not) with the destination. Hence, the results of this study differ from the findings reported by Alegre and Pou (2006), Gokovali et al. (2007) and Gomes de Menezes et al. (2008), which reported that having visited previously is a determining factor of length of stay in a destination.

\section{Conclusions}

This study reaffirms the positive relationship between cognitive and affective components (Baloglu \& McCleary, 1999; Beerli \& Martín, 2004) and the effect of these two constructs on satisfaction (Bigné et al., 2001; C. F. Chen \& Tsai, 2007; Chi \& Qu, 2008; Lee, 2009). Furthermore, the study analyses the relationship between familiarity, information sources, length of stay, cognitive evaluations, affective evaluations and satisfaction. Although academic literature has extensively demonstrated the relationship between cognitive evaluations, affective evaluations and satisfaction (Lee, 2009), insufficient work has been done regarding familiarity, information sources and length of stay, and no other research has linked them together, so more research in this area is needed. In addition, this study allows a better understanding of the effects of repeat visits to tourism destinations. This is an underdeveloped, but currently relevant area in academic literature, especially considering the academic and managerial implications; it has, as outlined in this paper.

Firstly, this study highlights the relevance of information sources as an antecedent of cognitive and affective evaluations. In particular, it is accepted that an official website positively affects cognitive evaluations and guidebooks influence affective evaluations. Thus, this result can be understood as a guideline of types of information each source of information should include. In the case of official websites, information should include practical information to prepare the trip. Guidebooks, on the other hand, should mainly appeal to emotions and feelings. Findings also reveal that individuals who are informed through recommendations are less likely to use the official website to organize their trip. This is quite logical if we consider that word-of-mouth has a high level of credibility (Gartner, 1994) because "consumers increasingly trust better their peers, rather than marketing messages" (Buhalis \& Law, 2008). Recommendations also save time and effort for individuals during the process of information search, and they allow individuals to concentrate their efforts on looking for the most interesting information for them in order to prepare their trip. So, information sources are seen as essential in 
influencing image perceptions and reducing the risk associated with expectations.

Secondly, length of stay is a complex construct that has been studied from various perspectives but needs to be studied more indepth. In particular, this study confirms that length of stay is not only a determinant factor for cognitive (Machado, 2010) but also influences affective evaluations. So, more time spent in a destination results in a positive evaluation of cognitive and affective components.

At the same time, length of stay is also influenced by types of information sources (Richards, 2002). In contrast to previous research, findings reveal that word-of-mouth is postulated as an influencing factor of length of stay. Thus, positive recommendations generated positively affect the length of stay. This is a relevant issue, especially considering the new Information and Communication Technologies (ICT) paradigm, where word-ofmouth is expanded though the net and "the tourist experience is not limited to the individual or people close to the tourist, but is shared at a worldwide level" (Camprubí, Guia \& Comas 2013: 205). Results also show that the use of previous experiences as an information source negatively affects the number of days that tourists spend at the destination.

Familiarity is also postulated as a relevant issue influencing information search. This study confirms that tourists that have previously visited the destination search out less information than others who are preparing the visit for the first time. This is in line with previous studies such as Carneiro and Crompton (2010) and Woodside and Dubelaar (2002) among others. Thus, in practical terms, guidebooks and official DMO's websites have absolutely no relevance for repeaters, who mainly use their previous experience to prepare their trip. Therefore, official websites should be adapted primarily to new tourists, and particularly those who have not received recommendations. Cities such as Barcelona, which are visited by a wide range of people, should aim to focus on new market regions or countries. This might imply, for example, stressing the relevance of languages on their websites.

However, the hypothesised relationship between familiarity and length of stay is rejected. Considering previous research does confirm a relationship between these two issues (Alegre \& Pou, 2006; Gokovali et al., 2007; Gomes de Menezes et al., 2008; Machado, 2010); it can be concluded that more research is needed in order to clarify in which cases a relationship between familiarity and length of stay exists or not. To prioritize future research in this direction, there is a need to investigate the differences between short breakers and long stayers in terms of behaviour, motivation and consumption patterns, and in turn, to study how familiarity patterns affect tourist behaviour. In summary, the results clearly show the interrelationship among the various constructs considered in the theoretical model and, partially, supporting previous research in the field. However, future research should focus primarily on two areas: length of stay and familiarity, which in some aspects are underdeveloped in academic literature.

Managerial implications are implicit in the conclusions exposed. Nevertheless, it can be stated, that destinations should consider the relevance of their sources of information and their power as influencing factors in the decision-making process, destination image formation and length of stay. In this sense, destinations should have the ability to use the most appropriate communication tools in each case and for each target, and to consider wordof-mouth as a powerful communication tool with a high credibility and an indirect cost for the destination (Camprubí et al., 2013; Gartner, 1994). So, knowing to what extent visitors repeat visits to a destination can, in turn, contribute to establishing more appropriate marketing strategies in order to encourage repetition of visitors and/or longer stays.

Finally, although the study has been carried out with a significant sample, data collection was only carried out over three months, so to better generalize results, sampling should be done over a year in order to identify variations in the different seasons throughout the year. 


\section{References}

Alegre, J., Pou, L. (2006) The length of stay in the demand for tourism. Tourism Management, 27(6), 1343-1355.

Alvarez, M. D., Campo, S. (2011) Controllable versus uncontrollable information sources: Effects on the image of Turkey. International Journal of Tourism Research, 13(4), 310-323.

Alvarez, M. D., Campo, S. (2014) The influence of political conflicts on country image and intention to visit: A study of Israel's image. Tourism Management, 40, 70-78.

Bagozzi, R. P., Yi, Y. (1988) On the evaluation of Structural Equation Models. Journal of the Academy of Marketing Science, 16(1), 74-94.

Baker, D. A., Crompton, J. L. (2000) Quality, satisfaction and behavioral intentions. Annals of Tourism Research, 27(3), 785804.

Baloglu, S. (2000) A Path Analytic Model of Visitation Intention Involving Information Sources, Socio-Psychological Motivations, and Destination Image. Journal of Travel \& Tourism Marketing, 8(3), 81-90.

Baloglu, S. (2001) Image variations of Turkey by familiarity index: informational and experiential dimensions. Tourism Management, 22, 127-133.

Baloglu, S., Brinberg, D. (1997) Affective Images of Tourism Destinations. Journal of Travel Research, 35(4), 11-15.

Baloglu, S., Mangaloglu, M. (2001) Tourism destination images of Turkey, Egypt, Greece, and Italy as perceived by USbased tour operators and travel agents. Tourism Management, 22(1), 1-9.

Baloglu, S., McCleary, K. W. (1999). A model of destination image formation, Annals of Tourism Research, 26(4), 868-897.

Barros, C. P., Machado, L. P. (2010) The length of stay in tourism. Annals of Tourism Research, 37(3), 692-706.

Beerli, A., Martín, J. D. (2004). Tourists' characteristics and the perceived image of tourist destinations: A quantitative analysis - A case study of Lanzarote, Spain. Tourism Management, 25, 623-636.

Berezan, O., Raab, C., Yoo, M., Love, C. (2013) Sustainable hotel practices and nationality: The impact on guest satisfaction and guest intention to return.
International Journal of Hospitality Management, 34, 227-233. doi:10.1016/j.ijhm.2013.03.010

Bigné Alcañiz, E., Sánchez García, I., Sanz Blas, S. (2009) The functionalpsychological continuum in the cognitive image of a destination: A confirmatory analysis. Tourism Management, 30(5), 715-723.

Bigné, J. E., Sánchez, M. I., Sánchez, J. (2001) Tourism image, evaluation variables and after purchase behaviour: Interrelationship. Tourism Management, 22, 607-616.

Bollen, K. A. (1989) Structural equations with latent variables. Wiley series in probability and mathematical statistics. (p. 514p.). New York: Wiley.

Brown, T. A. (2006) Confirmatory Factor Analysis for Applied Research. Methodology in the Social Sciences. New York, NY: Guilford Publications.

Bruwer, J., Lesschaeve, I. (2012) Wine Tourists' Destination Region Brand Image Perception and Antecedents: Conceptualization of a Winescape Framework. Journal of Travel \& Tourism Marketing, 29, 611-628.

Bruwer, J., Thach, L. (2013) Wine tourists' use of sources of information when visiting a USA wine region. Journal of Vacation Marketing, 19, 221-237.

Buhalis, D., Law, R. (2008) Progress in information technology and tourism management: 20 years on and 10 years after the Internet-The state of eTourism research. Tourism Management, 29(4), 609-623.

Camprubí, R., Guia, J., Comas, J. (2013) The new role of tourists in destination image formation. Current Issues in Tourism, 16(2), 203-209.

Carneiro, M. J., Crompton, J. L. (2010) The Influence of Involvement, Familiarity, and Constraints on the Search for Information about Destinations. Journal of Travel Research, 49(4), 451-470.

Chen, C. F., Tsai, D. (2007) How destination image and evaluative factors affect behavioral intentions? Tourism Management, 28, 1115-1122.

Chen, J. S. (2000) Cross-Cultural Differences in Travel Information Acquisition among 
Examining the role of familiarity, information sources, length of stay and satisfaction to the image perception model.

Tourists from Three Pacific-Rim Countries. Journal of Hospitality \& Tourism Research, 24(2), 239-251.

Chi, C. G. Q. (2012) An Examination of Destination Loyalty: Differences Between First-Time and Repeat Visitors. Journal of Hospitality \& Tourism Research, 36(1), 324.

Chi, C. G. Q., Qu, H. (2008) Examining the structural relationships of destination image, tourist satisfaction and destination loyalty: An integrated approach. Tourism Management, 29, 624-636.

Churchill, G. A., Surprenant, C. (1982) An Investigation into the Determinants of Customer Satisfaction. Journal of Marketing Research, 19(4), 491-504.

Crompton, J. L. (1979) An Assessment of the Image of Mexico as a Vacation Destination and the Influence of Geographical Location upon the Image. Journal of Travel Research, 17(4), 18-23.

Del Bosque, I. R., San Martín, H. (2008) Tourist satisfaction a cognitive-affective model. Annals of Tourism Research, 35(2), 551573.

Echtner, C. M., Ritchie, J. R. B. (1993) The measurement of destination image: An empirical assessment. Journal of Travel Research, 31(4), 3-13.

Fakeye, P. C., Crompton, J. L. (1991) Image Diferences Between Prospective, FirstTime and Repeat Visitors to the Lower Rio Grande Valley. Journal of Travel Research, 30(2), 10-16.

Fodness, D., Murray, B. (1997) Tourist information search. Annals of Tourism Research, 24, 503-523.

Fodness, D., Murray, B. (1999) A Model of Tourist Information Search Behavior. Journal of Travel Research, 37, 220-230.

Fornell, C. (1992) A National Customer Satisfaction Barometer: The Swedish Experience. Journal of Marketing, 1, 6-21.

Fornell, C., Larcker, D. F. (1981) Evaluating Structural Equation Models with Unobservable Variables and Measurement Error. Journal of Marketing Research, 18(1), 39-50.

Frías, D. M., Rodríguez, M. A., Alberto Castañeda, J., Sabiote, C. M., \& Buhalis, D. (2012) The Formation of a Tourist Destination's Image via Information
Sources: The Moderating Effect of Culture. International Journal of Tourism Research, 14(5), 437-450.

Gallarza, M. G., Gil, I., \& Calderón, H. (2002) Destination image: Towards a Conceptual Framework. Annals of Tourism Research, 29(1), 56-78.

García-Sánchez, A., Fernández-Rubio, E., \& Collado, M. D. (2013) Daily expenses of foreign tourists, length of stay and activities: evidence from Spain. Tourism Economics, 19(3), 613-630.

Gartner, W. C. (1994) Image Formation Process. Journal of Travel and Tourism Marketing, 2(3), 191-212.

Gokovali, U., Bahar, O., Kozak, M. (2007) Determinants of length of stay: A practical use of survival analysis. Tourism Management, 28(3), 736-746.

Gomes de Menezes, A., Moniz, A., \& Cabral, J. (2008) The determinants of length of stay of tourists in the Azores. Tourism Economics, 14(1), 205-222.

Gunn, C. A. (1972) Vacationscape. Designing Tourist Regions. Washington DC: Taylor and Francis/University of Texas.

Gursoy, D., Chen, J. S. (2000) Competitive analysis of cross cultural information search behavior. Tourism Management, 21(6), 583-590.

Gursoy, D., McCleary, K. W. (2004) An integrative model of tourists' information search behavior. Annals of Tourism Research, 31(2), 353-373.

Hanlan, J., Kelly, S. (2005) Image formation, information sources and an iconic Australian tourist destination. Journal of Vacation Marketing, 11, 163-177.

Hernández Maestro, R. M., Muñoz Gallego, P. A., \& Santos Requejo, L. (2007) The moderating role of familiarity in rural tourism in Spain. Tourism Management, 28, 951-964.

Hildreth, J. (2007) The Saffron European City Brand Barometer. Revealing which cities get the brands they deserve.

Hong, S. kwon, Lee, S. W., Lee, S., Jang, H. (2009) Selecting Revisited Destinations. Annals of Tourism Research, 36(2), 268294.

Hsu, C. H. C., Wolfe, K., Kang, S. K. (2004) Image Assessment for a Destination with 
Prats, L., R. Camprubí and L. Coromina (2016) / European Journal of Tourism Research 13, pp. 5-22

Limited Comparative Advantages.

Tourism Management, 25, 121-126.

Hu, L., Bentler, P. M. (1999) Cut-off criteria for fit indexes in covariance structure analysis: Conventional criteria versus new alternatives. Structural Equation Modeling: A Multidisciplinary Journal, 6(1), 1-55.

Josiassen, A., Assaf, A. G., Woo, L., Kock, F. (2015) The Imagery - Image Duality Model : An Integrative Review and Advocating for Improved Delimitation of Concepts. Journal of Travel Research, (in press), DOI: 10.1177/0047287515583358

Kim, H., Richardson, S. L. (2003) Motion picture impacts on destination images. Annals of Tourism Research, 30(1), 216-237.

Kim, W., Ma, X., Kim, D. J. (2006) Determinants of Chinese hotel customers' e-satisfaction and purchase intentions. Tourism Management, 27, 890-900.

Kline, R. B. (2011) Principles and practice of structural equation modeling. Methodology in the social sciences (3rd ed., p. xvi, 427 p.). New York: Guilford Press.

Kotler, P., Haider, D. H., Rein, I. (1993) Marketing Places: Attracting Investment, Industry, and Tourism to Cities, States, and Nations. New York: Free Press.

Kralj, A., Solnet, D. (2010) Service climate and customer satisfaction in a casino hotel: An exploratory case study. International Journal of Hospitality Management, 29(4), 711-719.

Lee, T. H. (2009) A structural model for examining how destination image and interpretation services affect future visitation behavior: a case study of Taiwan's Taomi eco-village. Journal of Sustainable Tourism, 17(6), 727-745.

Li, H., Ye, Q., Law, R. (2013) Determinants of Customer Satisfaction in the Hotel Industry: An Application of Online Review Analysis. Asia Pacific Journal of Tourism Research, 18(7), 784-802.

Lin, C.-H., Morais, D. B., Kerstetter, D. L., Hou, J.-S. (2007) Examining the Role of Cognitive and Affective Image in Predicting Choice Across Natural, Developed, and Theme-Park Destinations. Journal of Travel Research, 46(2), 183194.

Luo, M., Feng, R., Cai, L. A. (2004) Information Search Behavior and Tourist
Characteristics. Journal of Travel \& Tourism Marketing, 17, 15-25.

MacCallum, R. C., Browne, M. W., Sugawara, H. M. (1996) Power analysis and determination of sample size for covariance structure modeling. Psychological Methods, 1(2), 130-149.

Machado, L. P. (2010) Does destination image influence the length of stay in a tourism destination? Tourism Economics, 16(2), 443-456.

McCartney, G., Butler, R., Bennett, M. (2008) A strategic use of the communication mix in the destination image-formation process. Journal of Travel Research, 47(2), 183196.

McDowall, S. (2010) International Tourist Satisfaction and Destination Loyalty: Bangkok, Thailand. Asia Pacific Journal of Tourism Research, 15(1), 21-42.

Millán, A., Esteban, A. (2004) Development of a multiple-item scale for measuring customer satisfaction in travel agencies services. Tourism Management, 25, 533546.

Nam, J. H., Lee, T. J. (2011) Foreign travelers' satisfaction with traditional Korean restaurants. International Journal of Hospitality Management, 30, 982-989.

Palau-Saumell, R., Forgas-Coll, S., SánchezGarcía, J., Prats-Planagumà, L. (2013) Tourist Behavior Intentions and the Moderator Effect of Knowledge of UNESCO World Heritage Sites: The Case of La Sagrada Familia. Journal of Travel Research, 52(3), 364-376.

Palau-Saumell, R., Forgas-Coll, S., SánchezGarcía, J., Prats-Planagumà, L. (2014) Managing dive centres: SCUBA divers' behavioural intentions. European Sport Management Quarterly, 14(4), 422-443.

Papadimitriou, D., Apostolopoulou, A., Kaplanidou, K. (2015) Destination Personality, Affective Image, and Behavioral Intentions in Domestic Urban Tourism. Journal of Travel Research, 54, 302-315.

Phelps, A. (1986) Holiday destination image the problem of assessment: An example developed in Menorca. Tourism Management, 7(3), 168-180. 
Richards, G. (2002) Tourism Attraction System. Exploring Cultural Behavior. Annals of Tourism Research, 29(4), 1048-1064.

Ritchie, J. B., Crouch, G. I. (2003) The Competitive Destination: A Sustainable Tourism Perspective. Willinford, Uk: Cabi publishing.

Ross, G. F. (1993) Ideal and actual images of backpacker visitors to Northern Australia. Journal of Travel Research, 32(2), 54-57.

Russel, J. A., Ward, L. M., \& Pratt, G. (1981) Affective Quality Attributed to Environments: A Factor Analytic Study. Environment and Behavior, 13(3), 259288.

Ryan, C., Pike, S. (2004) Destination Positioning Analysis through a Comparison of Cognitive, Affective, and Conative Perceptions. Journal of Travel Research, 42(4), 333-342.

Ryu, K., Han, H., Jang, S. (2010) Relationships among hedonic and utilitarian values, satisfaction and behavioral intentions in the fast-casual restaurant industry. International Journal of Contemporary Hospitality Management, 22(3), 416-432.

Salmasi, L., Celidoni, M., Procidano, I. (2012) Length of Stay: Price and Income SemiElasticities at Different Destinations in Italy. International Journal of Tourism Research, 14(6), 515-530.

Saris, W. E., Satorra, A., van der Veld, W. (2009) Testing Structural Equation Models or Detection of Misspecifications? Structural Equation Modeling: A Multidisciplinary Journal, 16(4), 561-582.

Sonmez, S. F., Sirakaya E. (2002) A Distorted Destination Image? The Case of Turkey. Journal of Travel Research, 41(2), 185196.
Suriñach, J. (2010) Estudi de l'impacte econòmic de l'activitat turística a la ciutat de Barcelona. Pla Estratègic de Turisme de Barcelona.

Tasci, A. D. A., Gartner, W. C. (2007) Destination Image and Its Functional Relationships. Journal of Travel Research, 45(4), 413-425.

Tasci, A. D. A., Gartner, W. C., Cavusgil, S. T. (2007) Conceptualization and Operationalization of Destination Image. Journal of Hospitality \& Tourism Research, 31, 194-223.

Thrane, C., Farstad, E. (2012) Tourists' length of stay: the case of international summer visitors to Norway. Tourism Economics, 18(5), 1069-1082.

Tse, D., Wilton, P. (1988) Models of consumer satisfaction formation: an extension. Journal of Marketing, 25(2), 204-212.

Vogt, C. A., Stewart, S. I. (1998) Affective and cognitive effects of information use over the course of a vacation. Journal of Leisure Research, 30(4), 498-520.

Woodside, A. G., Dubelaar, C. (2002) A General Theory of Tourism Consumption Systems: A Conceptual Framework and an Empirical Exploration. Journal of Travel Research, 41, 120-132.

Woodside, A. G., King, R. I. (2001) An Updated Model of Travel and Tourism PurchaseConsumption Systems. Journal of Travel \& Tourism Marketing, 10(1), 3-27.

Wu, C. H. J., Liang, R.-D. (2009) Effect of experiential value on customer satisfaction with service encounters in luxury-hotel restaurants. International Journal of Hospitality Management, 28, 586-593.. 